\title{
Response Surface Models to Predict Broiler Performance and Applications for Economic Analysis
}

- Author(s)
Faria Filho DE'
Rosa PS
Torres KAA ${ }^{3}$
Macari M
Furlan RL $^{3}$
1 Universidade Federal de Minas Gerais,
Instituto de Ciências Agrárias, Setor
Acadêmico de Zootecnia. Montes Claros,
Brasil.
2 Embrapa Suínos e Aves. Concórdia, SC,
Brasil.
Universidade Estadual Paulista, Faculdade
de Ciências Agrárias e Veterinárias,
Departamento de Morfologia e Fisiologia
Animal. Jaboticabal, SP, Brasil.

Mail Address

Daniel Emygdio de Faria Filho

Universidade Federal de Minas Gerais Instituto de Ciências Agrárias

Av. Universitária, n. 1000

Bairro Universitário. Caixa postal 135

39.404-006. Montes Claros, MG, Brasil.

E-mail: fariafilho@ufmg.br

\section{Keywords}

Crude protein, environmental temperature, regression analysis, response surface, slaughter age, systematic literature review

\section{ABSTRACT}

A study was carried out to elaborate response surface models using broiler performance data recovered from literature in order to predict performance and elaborate economic analyses. Nineteen studies published between 1995 and 2005 were retrieved using the systematic literature review method. Weight gain and feed conversion data were collected from eight studies that fulfilled the pre-established inclusion criteria, and a response surface model was adjusted using crude protein, environmental temperature, and age as independent variables. The models produced for weight gain $\left(r^{2}=0.93\right)$ and feed conversion $\left(r^{2}=\right.$ $0.85)$ were accurate, precise, and not biased. Protein levels, environmental temperature and age showed linear and quadratic effects on weight gain and feed conversion. There was no interaction between protein level and environmental temperature. Age and crude protein showed interaction for weight gain and feed conversion, whereas interaction between age and temperature was detected only for weight gain. It was possible to perform economic analyses to determine maximum profit as a function of the variables that were included in the model. It was concluded that the response surface models are effective to predict the performance of broiler chickens and allow the elaboration of economic analyses to optimize profit.

\section{INTRODUCTION}

The precise determination of the cost/benefit ratio in broiler rearing depends on the development of mathematical models capable of predicting growth and feed intake as a function of the factors that affect such variables (Oviedo-Rondón \& Waldroup, 2002). Dietary protein (Kidd et al., 2005), environmental temperature (Faria Filho, 2003), and slaughter age (Zuidhof, 2005) are known to affect performance, carcass characteristics, and economic viability of broiler chicken production. Consequently, mathematical models that include such variables may help decision-making on which nutritional and management procedures should be used to optimize profit. Mathematical modeling is thus an important tool to the poultry industry, and has generated a large number of studies on this issue (Eits et al., 2005 a,b; Sakomura et al., 2005; Sklan \& Noy, 2005; Zuidhof, 2005).

Among the available mathematical tools, response surface models are of great practical applicability, as they allow analyzing more than one factor simultaneously by means of first and second order polynomials, and are also able to assess the interaction between the factors involved in the study (Freund \& Littell, 2000). Eits et al. (2005a) emphasized that the models should be practical (to include variables that are known by nutritionists), flexible (to involve variables such as sex, nutritional levels, environmental temperature, among others), and precise (derived from 
Faria Filho DE, Rosa PS, Torres KAA, Macari M, Furlan RL many databases). In such context, models have been developed based on literature results in order to predict performance, carcass characteristics (Eits et al., 2005 a) and profit (Eits et al., 2005 b) of broiler rearing as a function of the crude protein levels and have shown satisfactory adjustments.

A consistent retrieval of already published research may be accomplished by using the method of systematic literature review, also known as systematic review (Castro et al., 2002). Such review is the scientific technique of screening literature through specific methods to identify, select, and critically evaluate the relevant studies. Therefore, many factors must be previously defined and mentioned in the text, such as the search strategy, the databases, the time frame, and the criteria for including the studies. The studies that are not included must be cited, and their exclusion must be justified. Therefore, systematic reviews are reproducible and generally not biased.

The objective of this study was to elaborate response surface models based on literature data that include the independent variables crude protein, environmental temperature and slaughter age in order to predict performance and elaborate economic analyses.

\section{MATERIAL AND METHODS}

\section{Study screening}

A systematic review was performed according to Castro et al. (2002); by means of electronic search of the key words environmental temperature, dietary protein and broiler chickens in the databases Biological Abstracts, Cab Abstracts, Medline, and Scielo in the period between 1995 and 2005. Afterwards, the references of the retrieved studies were also searched.The non-published results of research studies carried out by our group were also included (Departamento de Morfologia e Fisiologia from Faculdade de Ciências Agrárias e Veterinárias, Universidade Estadual Paulista - Jaboticabal / São Paulo / Brazil).

\section{Inclusion criteria}

The studies included in the analysis fulfilled the following criteria: 1) the studies evaluated the effects of temperature in environment controlled rooms and the levels of crude protein on the broiler chickens performance of commercial strains; 2 ) the studies presented number of repetitions, number of birds per repetition, nutritional levels, and performance results in tables; 3 ) the trials started between 20 and 23 days
Response Surface Models to Predict Broiler Performance and Applications for Economic Analysis

of age and lasted more than one week; 4) during the initial period, the broilers were reared under thermoneutral conditions.

\section{Data collection}

Means of weight gain ( $\mathrm{g} / \mathrm{bird} / \mathrm{d})$ and feed conversion $(\mathrm{g} / \mathrm{g})$ were collected from the studies that fulfilled the inclusion criteria. Such data were entered in Microsoft Excel ${ }^{\circledR}$ spreadsheets together with information on temperature $\left({ }^{\circ} \mathrm{C}\right)$, dietary protein levels $(\%)$, mean age in days ([initial age+slaughter age] / 2), number of replicates, and number of birds per replicate.

\section{Statistical analysis}

Surface response models were adjusted (Freund \& Littell, 2000). The following model has been proposed:

$$
\begin{aligned}
& Y_{i}=\beta_{0}\left(X_{i 0}\right)+\beta_{1}\left(X_{i 1}\right)+\beta_{2}\left(X_{i 2}\right)+\beta_{3}\left(X_{i 3}\right)+\beta_{4}\left(X_{i 4}\right)+\beta_{5} \\
& \left(X_{i 5}\right)+\beta_{6}\left(X_{i 6}\right)+\beta_{7}\left(X_{i 1} X_{i 3}\right)+\beta_{8}\left(X_{i 1} X_{i 5}\right)+\beta_{9}\left(X_{i 3} X_{i 5}\right)+\varepsilon_{i} \\
& Y_{i}=\text { body weight gain (g/bird/day) or feed } \\
& \mathrm{X}_{\mathrm{i0}}=1 \text { (intercept); } \\
& X_{i 1}=\text { mean age (days) in the } i^{\text {th }} \text { observation; [mean } \\
& X_{i 2}=X_{i 1}^{2} \\
& X_{i 3}=\text { environmental temperature }\left({ }^{\circ} \mathrm{C}\right) \text { in the } i^{\text {th }}
\end{aligned}
$$

Data were analyzed for the presence of outliers, homogeneity of variance, and normality of studentized errors of residuals (Freund \& Littell, 2000). Parameters showing probabilities lower than $5 \%$ were kept in the model.

\section{Model validation}

The developed models were tested for their 
accuracy, precision, and bias (Harlow \& Ivey, 1994). Accuracy identifies if there are differences between the model-predicted values and the observed values. Accuracy was assessed using a T test in order to test the hypothesis that the sum of the differences between observed and predicted values was null. Precision verifies if the model predicts the distribution around the mean. It was assessed by plotting a graph with the studentized errors and the observed values. Bias represents systematic failures that the model may have and was verified by plotting the predicted values against the observed values.

\section{Economic analysis}

A program was elaborated in a Microsoft Excel ${ }^{\circledR}$ spreadsheet to determine which protein level, rearing temperature, and slaughter age promoted maximum profit according to market changes (the diet and the live bird prices). The resulting equations for weight gain and feed conversion were used to calculate income, cost, and profit, which were defined by:

Income live bird $=$ live weight $x$ price per $\mathrm{kg}$ of live bird;

Cost $=\quad[$ (feed intake $\mathrm{x}$ diet price $) /$ $0.70]$. Therefore, feeding costs were considered to be $70 \%$ of the total cost. Feed intake was determined as the product between weight gain and feed conversion;

Profit $=\quad$ Income live bird - cost.

Live weights at 1 and 21 days of age, feed intake from 1 to 21 days of age, diet prices, and live bird were established as input variables to be defined by the program user. Microsoft Excel ${ }^{\circledR}$ Solver was then used to define which protein level, temperature, and slaughter age resulted in maximum profit.

A simulation of profit maximization was performed; the values considered as normal market scenario were the cost of $R \$ 0.531 / \mathrm{kg}$ diet for the diet fed from 21 days to slaughter age and the income of $R \$ 1.40 /$ per $\mathrm{kg}$ of live bird. Three unfavorable market situations were simulated: (A) diet cost 20\% higher; (B) price paid for the live bird 20\% lower; $(A+B)$ both situations occurring simultaneously. Such market situations were applied to optimize the slaughter age that promoted maximum profit for broilers reared at different temperatures and to optimize the levels of crude protein that resulted in maximum profit when slaughter age was changed. Additionally, weight gain and feed conversion were optimized for the situations already described.

\section{RESULTS AND DISCUSSION}

\section{Systematic literature review}

The systematic review retrieved 19 studies, out of which 11 did not fulfill the inclusion criteria: the trial was not carried out in rooms with controlled environment (Rahman et al., 2002; Zarate et al., 2003 $a, b)$; the trial did not start between 20 and 23 days of age (Cahaner et al., 1995; Faria Filho et al., 2005, 2006; Temim et al., 1999, 2000 a,b); the trial did not use a commercial broiler strain and lasted less than one week (Gonzalez-Esquerra \& Lesson, 2005); the performance results were not presented (Hruby et al., 1995).

The eight studies that fulfilled the criteria were Alleman \& Leclercq (1997), Cheng et al. (1997 a,b), Cheng et al. (1999), and four studies from our group (Faria Filho, 2003, 2006). Such studies involved only Arbor Acres \& Ross, Cobb and Ross male broiler chickens reared on litter or in cages, and the age varied between 21 and 49 days old. Rearing temperatures varied from 20 to $35^{\circ} \mathrm{C}$, crude protein levels from 16 to $24 \%$, and initial weights from 784 to $899 \mathrm{~g}$.

\section{Surface response}

The weight gain and feed conversion estimated parameters of the response surface model are shown in Table 1.

The linear and quadratic terms of the polynomials for crude protein levels, broiler mean age, and environmental temperature were significant for weight gain and feed conversion (Table 1). These results are shown in Figure 1 for a hypothetical situation (45-dayold broilers reared at $25^{\circ} \mathrm{C}$ and fed with $20 \%$ protein), in which one of the three factors was changed and the others were kept constant.

Protein levels that optimized weight gain and feed conversion were 20.5 and $21.3 \%$, respectively (Figure 1 -A). Such values are higher than those recommended by Rostagno et al. (2005), of $19.7 \%$ CP for the period between 22 and 33 days of age and 18.3\% CP from 34 to 42 days of age. Nevertheless, the values are similar to the NRC (1994) recommendations, of $20 \%$ protein for broilers in the grower phase.

Slaughter ages that optimized weight gain and feed conversion were 45.5 and 36.6 days, respectively (Figure 1-B). Sakomura et al. (2005) determined growing parameters of Ross ${ }^{\circledR}$ broilers from 1 to 70 days of age and observed that the growth rate ( $g /$ day) for 


\begin{tabular}{|c|c|c|c|c|c|c|}
\hline \multirow[t]{2}{*}{ Variables } & \multicolumn{3}{|c|}{ Weight gain } & \multicolumn{3}{|c|}{ Feed conversion } \\
\hline & Parameters & SEM & $\mathbf{P}$ & Parameters & SEM & $\mathbf{P}$ \\
\hline Intercept & -1742.17 & 154.32 & $<0.0001$ & 26.16 & 2.56 & $<0.0001$ \\
\hline Temperature (TP) & 15.5082 & 2.6045 & $<0.0001$ & -0.2897 & 0.0337 & $<0.0001$ \\
\hline $\mathrm{TP}^{2} \star$ & -0.2836 & 0.0324 & $<0.0001$ & 0.0057 & 0.0006 & $<0.0001$ \\
\hline Protein (CP) & 27.7798 & 6.2574 & $<0.0001$ & -0.6040 & 0.1097 & $<0.0001$ \\
\hline$C P^{2} *$ & -0.3219 & 0.1001 & 0.0019 & 0.0052 & 0.0017 & 0.0040 \\
\hline Age $(A)$ & 89.3235 & 8.0757 & $<0.0001$ & -0.9821 & 0.1396 & $<0.0001$ \\
\hline$A^{2 *}$ & -1.2780 & 0.1282 & $<0.0001$ & 0.0128 & 0.0022 & $<0.0001$ \\
\hline$T P \times C P$ & - & - & $>0.05$ & - & - & $>0.05$ \\
\hline TP $\times A$ & -0.0905 & 0.0551 & 0.0420 & - & - & $>0.05$ \\
\hline$C P \times A$ & -0.4428 & 0.1486 & 0.0038 & 0.0117 & 0.0026 & $<0.0001$ \\
\hline$r^{2 * \star}$ & 0.93 & & & 0.85 & & \\
\hline$N * * *$ & 88 & & & 85 & & \\
\hline
\end{tabular}

${ }^{*}$ quadratic effect. ${ }^{* *} r^{2}=$ coefficient of determination; ${ }^{* * *} N=$ number of observations.

males is maximum at 42 days, which is close to the 45.5 days of age in the present study. Besides, feed conversion gradually worsens with age (Cobb, 2001), and the slaughter age that minimizes feed conversion is younger than the age that maximizes weight gain.

As to rearing temperature, better weight gain and feed conversion were obtained at 22.1 and $25.4^{\circ} \mathrm{C}$, respectively (Figure $1-C$ ). These results evidence that the optimal rearing temperature depends on the characteristic to be optimized. Faria Filho et al. (2005) observed that cold-exposed broilers during the starter phase showed higher weight gain than birds reared in a thermoneutral environment, but feed conversion was worse. The mean rearing temperature recommended by Cobb (2001) for birds from 21 days of age until slaughter is $22.5^{\circ} \mathrm{C}$, which is similar to that obtained for body weight gain optimization.

There was no significant interaction between environmental temperature and crude protein levels for weight gain and feed conversion (Table 1). The independence between the two factors on weight gain and feed conversion indicates that the effect of a particular protein level is the same for broilers reared either at thermoneutral or high temperatures. Nutritionists oppose to the increase in the dietary protein levels when broilers are submitted to heat because of the high caloric increment of protein (Musharaf \& Latshaw, 1999). Nevertheless, Temim et al. (2000b) verified that high-protein diets (25\%) had no effect on the turnover of the muscles Pectoralis major, Sartorius, and Gastrocnemius of broilers reared at 22 or $32^{\circ} \mathrm{C}$. Such results indicate that high-protein diets do not increase heat production, since muscle turnover is highly associated to heat production (Macleod, 1997). The lack of heat production in broilers fed high protein levels was also found by Faria Filho
(2006). These findings support the utilization of diets with high protein levels even in hot environments.

There was a significant interaction between age and crude protein levels for weight gain and feed conversion (Table 1). In Figure 2-A, the response surface graph shows the behavior of such interaction for feed conversion. It is observed that 35-day-old broilers improved feed conversion when high protein levels were fed; on the other hand, the effect gradually disappeared with age. The result for weight gain was similar (graph not shown).

Age and environmental temperature showed a significant interaction for weight gain (Table 1). The results presented in Figure 2-B show that weight gain decreased as age increased when birds were heatexposed. Such results occurred because broilers become very susceptible to heat during the grower phase (after 21 days of age). During growth, feathering is completed and the area/volume ratio of the birds decreases; these are the main reasons why older birds have difficulty to maintain thermal homeostasis during heat exposure. May \& Lott (2001) elaborated response surface models and observed that the birds became more sensitive to heat as body weight (age) Increased.

\section{Model validation}

Table 1 shows the coefficient of determination $\left(r^{2}\right)$ values for weight gain $\left(r^{2}=0.93\right)$ and feed conversion $\left(r^{2}=0.85\right)$, indicating that the developed models satisfactorily explained the data variation. The fitted models did not explain only $7 \%$ of the variations in weight gain and $15 \%$ of the variations in feed conversion. This lack of fitting might be explained by factors that were not included in the model, such as dietary energy levels, amino acid supplementation, and stocking density, in addition to factors that were not controlled. 
Faria Filho DE, Rosa PS, Torres KAA, Macari M, Furlan RL
Response Surface Models to Predict Broiler Performance and Applications for Economic Analysis
(A)

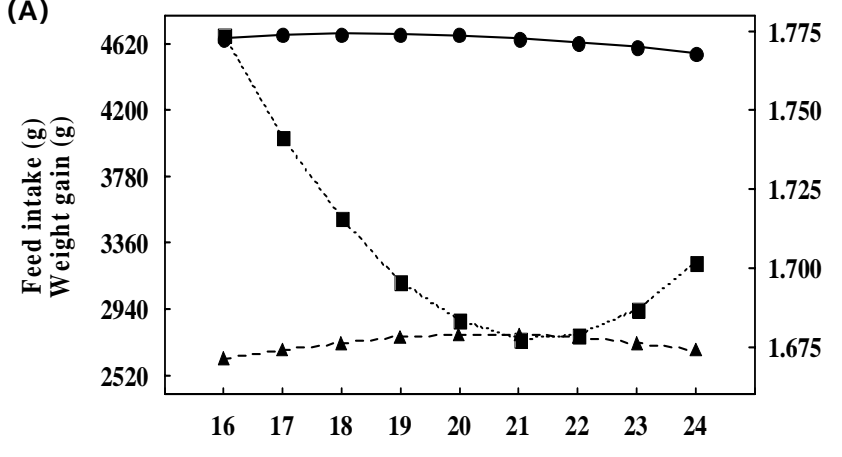

(B)

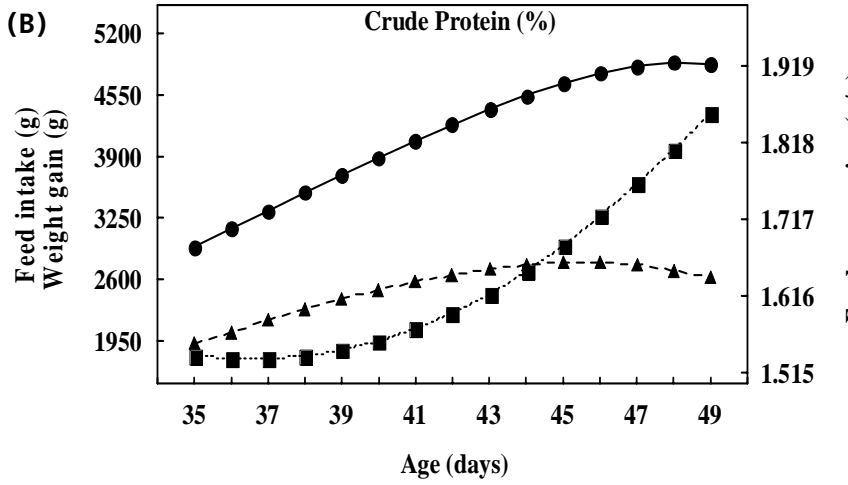

(C)

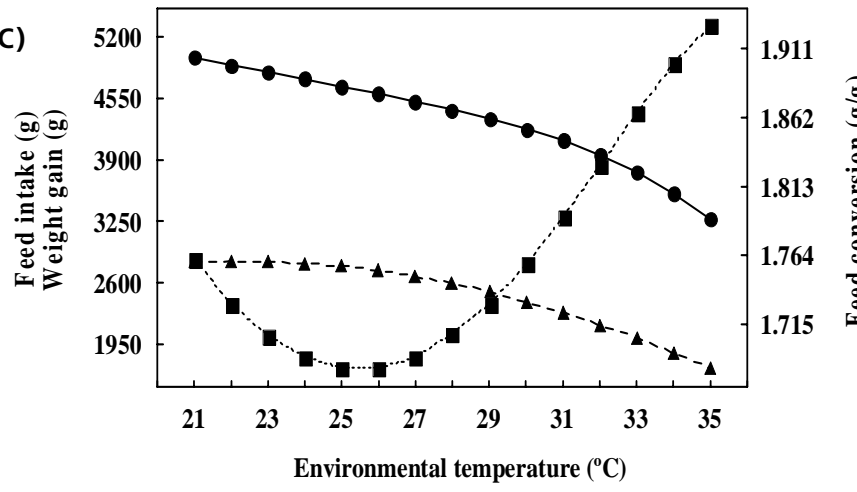

Feed Intake

Weight gain

Feed conversion

Figure 1 - Feed intake, weight gain, and feed conversion predicted as a function of the dietary crude protein level (A), age (B), and rearing temperature $(C)$ in which one of the three factors was changed whereas the other two were kept constant.

Accuracy was measured using a $T$ test in order to verify the hypothesis that the sum of the differences between the values predicted by the model and the observed values was zero. The hypothesis has not been refuted for weight gain $(p=0.61)$, nor for feed conversion ( $p=0.34$ ), which indicates the good accuracy of the model.

The models also adequately predicted the distribution around the mean (precision). Figures 3-A and $3-C$ show that the studentized errors are well
(A)

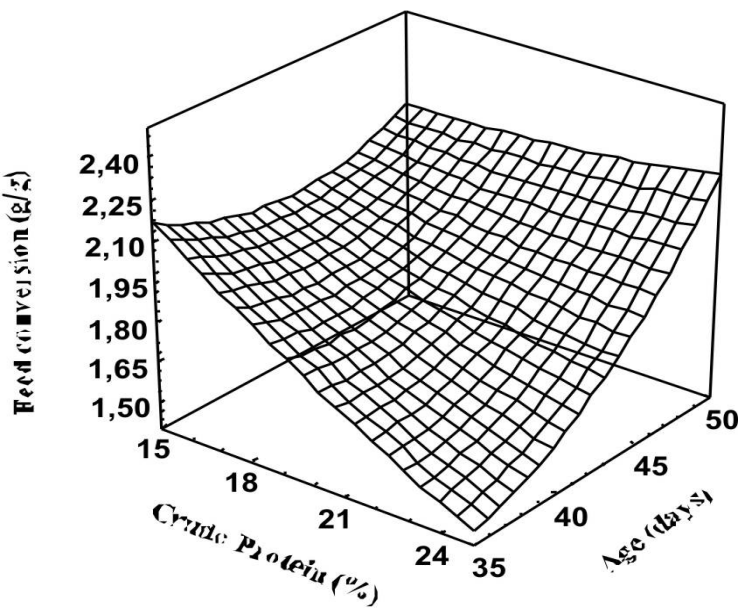

(B)

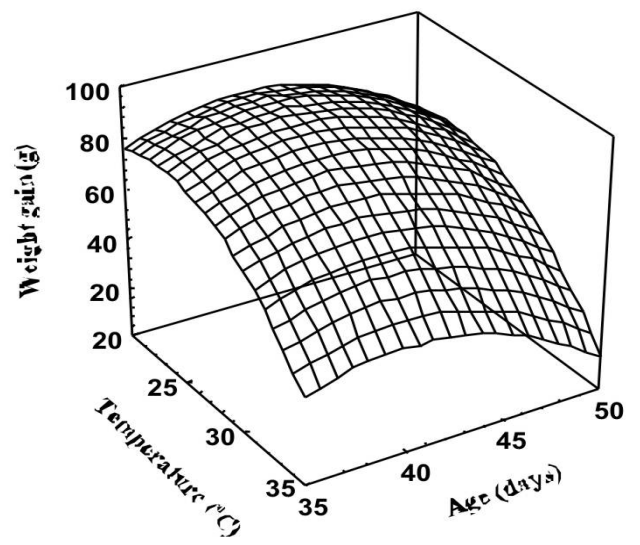

Figure 2 - Interaction between protein and age for feed conversion (A) and between age and temperature for weight gain (B) of broiler chickens (response surface graph).

distributed around the mean for weight gain and feed conversion, respectively, indicating the good precision of the models.

The graph of predicted versus observed values allows verifying the presence of biases. For a nonbiased model, the graph must have the aspect of a straight line. In Figures 3-B and 3-D, the dotted line represents the ideal situation, whereas the full line is the curve estimated by the least square method. Both for weight gain (Figure 3-B) and for feed conversion (Figure 3-D), there was good proximity between the two curves, indicating the absence of biases.

It is worth noting that the data used for the accuracy, precision, and bias tests were the same as those used to elaborate the model, which is not the ideal situation. Therefore, it is suggested that the models are tested with other databases, preferably with field data, for a complete validation of the model. 
Faria Filho DE, Rosa PS, Torres KAA, Macari M, Furlan RL

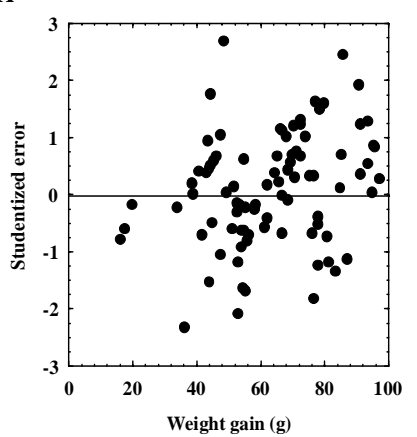

C

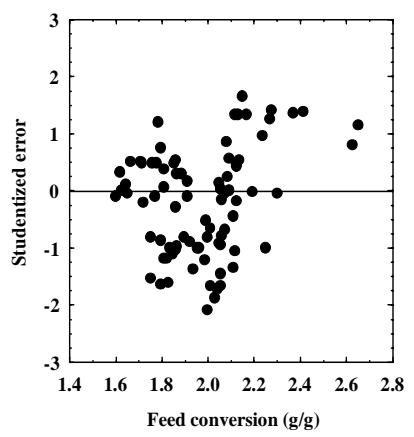

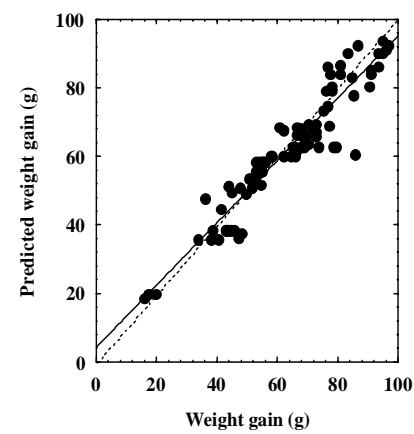

D

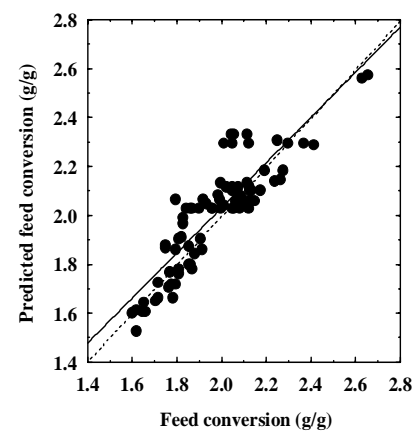

Figure 3 - Evaluation of precision ( $A$ and $C$ ) and bias ( $B$ and $D$; the dotted line represents the optimal situation, whereas the full line is the curve estimated by the least square method) of the response surface models elaborated for weight gain and feed conversion.

\section{Economic analysis}

Figure 4-A shows the optimization of the slaughter age that promoted better profit or performance as a function of rearing temperature and market conditions.

In all simulated market scenarios, it was seen that broilers reared at $32^{\circ} \mathrm{C}$ should be slaughtered earlier to optimize profit or performance as compared to birds reared at 22 or $27^{\circ} \mathrm{C}$. In addition, in unfavorable market scenarios (high price of the diet, $A$; low price of the live bird, B; or both conditions simultaneously, $A+B)$, it was more profitable to slaughter the birds earlier, particularly under the situation $\mathrm{A}+\mathrm{B}$. It is interesting to note that the slaughter age that promotes maximum weight gain was considerably higher than the age that optimizes profit or feed conversion.

Figure 4-B shows the optimization of protein levels that promoted greater profit or performance as a function of slaughter age and market scenarios. It was seen that protein requirements decreased with increasing slaughter age in any market situation. Furthermore, the imposed market scenarios (normal, $A, B$, and $A+B$ ) did not change protein requirements for maximum profit. Protein requirements for optimizing weight gain and feed conversion were higher than
Response Surface Models to Predict Broiler Performance and Applications for Economic Analysis

A

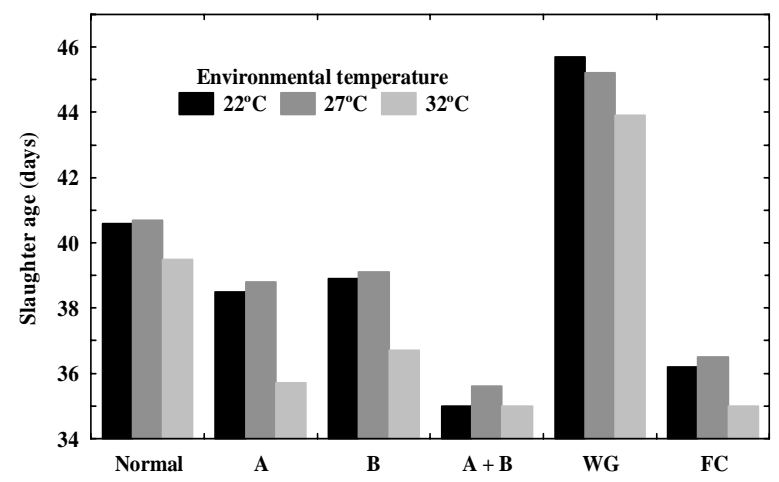

B

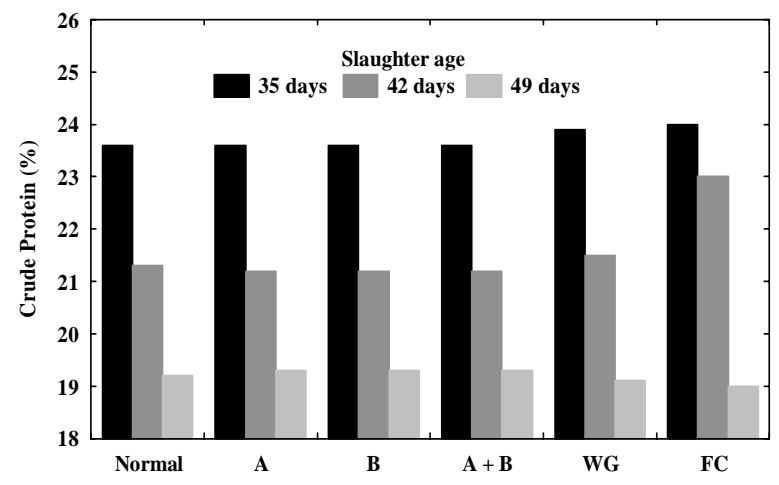

Figure 4 - Slaughter age optimization as a function of rearing temperature (A), and protein levels as a function of slaughter age (B) and market conditions. Normal $=$ normal market scenario; $A=$ diet price $20 \%$ higher; $B=$ live bird price $20 \%$ lower; $A+B=$ both $A$ and $\mathrm{B}$ occurring simultaneously; $\mathrm{GP}=$ optimization for weight gain; $C A$ = optimization for feed conversion.

protein requirements for optimizing profit.

\section{CONCLUSIONS}

1 - Response surface models are efficient in predicting weight gain and feed conversion in broiler chickens.

2 - The constructed models allowed to determine the dietary protein levels, the rearing temperature and the slaughter age of broiler chickens that would generate maximum profit as a function of market conditions.

\section{REFERENCES}

Alleman F, Leclercq B. Effect of dietary protein and environmental temperature on growth performance and water consumption of male broiler chickens. British Poultry Science 1997; 38:607-610.

Cahaner A, Pinchasov Y, Nir I. Effect of dietary protein under high ambient temperature on body weight, breast meat yield, and 


\section{Faria Filho DE, Rosa PS, Torres KAA, Macari M, Furlan RL}

abdominal fat deposition of broiler stocks differing in growth rate and fatness. Poultry Science 1995; 74:968-975.

Castro AA, Saconato H, Guidugli F, Clark OAC. Curso de revisão sistemática e metanálise [Online]. São Paulo: LED-DIS/UNIFESP; 2002 [cited 2005 nov 10]. Available from: http://www.virtual.epm.br/ cursos/metanalise.

Cheng TK, Hamre ML, Coon CN. Effect of environmental temperature, dietary protein, and energy levels on broiler performance. Journal of Applied Poultry Research 1997a; 6:1-17.

Cheng TK, Hamre ML, Coon CN. Responses of broilers to dietary protein levels and amino acid supplementation to low protein diets at various environmental temperatures. Journal of Applied Poultry Research 1997b; 6:18-33.

Cheng TK, Hamre ML, Coon CN. Effect of constant and cyclic environmental temperatures, dietary protein, and amino acid levels on broiler performance. Journal of Applied Poultry Research 1999; $8: 426-439$.

Cobb. Guia de manejo para frango de corte COBB 500. S.I.: s.n; 2001. p.20.

Eits RM, Kwakkel RP, Verstegen MWA, Den Hartog LA. Dietary balanced protein in broiler chickens. 1. A flexible and practical tool to predict dose-response curves. British Poultry Science 2005a; 46:300-309.

Eits RM, Giesen GWJ, Kwakkel RP, Verstegen MWA, Den Hartog LA. Dietary balanced protein in broiler chickens. 2. An economic analysis. Bristish Poultry Science 2005 b; 46:310-317.

Faria Filho DE. Efeito de dietas com baixo teor protéico, formuladas usando o conceito de proteína ideal, para frangos de corte criados em temperaturas fria, termoneutra e quente [dissertação]. Jaboticabal (SP): Universidade Estadual Paulista; 2003.

Faria Filho DE. Aspectos produtivos, metabólicos, econômicos e ambientais da nutrição protéica para frangos de corte expostos ao calor [tese]. Jaboticabal (SP): Universidade Estadual Paulista; 2006.

Faria Filho DE, Rosa PS, Vieira BS, Macari M, Furlan RL. Protein levels and environmental temperature effects on carcass characteristics, performance and nitrogen excretion of broiler chickens from 7 to 21 days of age. Brazilian Journal of Poultry Science 2005; 7:247253.

Faria Filho DE, Rosa PS, Figueiredo DF, Dahlke F, Macari M, Furlan RL. Dietas de baixa proteína no desempenho de frangos criados em diferentes temperaturas. Pesquisa Agropecuária Brasileira 2006; 41:101-106.

Freund RJ, Littell RC. SAS ${ }^{\circledR}$ System for regression. $4^{\text {th }}$ ed. Cary (NC): SAS Institute; 2000.

Gonzalez-Esquerra R, Lesson S. Effects of acute versus chronic heat stress on broiler response to dietary protein. Poultry Science 2005; 84:1562-1569.

Harlow HB, Ivey FJ. Accuracy, precision, and commercial benefits of
Response Surface Models to Predict Broiler Performance and Applications for Economic Analysis

growth modeling for broilers. Journal of Applied Poultry Research 1994; 3:391-402.

Hruby N, Hamre ML, Coon CN. Predicting amino acid requirements for broilers at $21.1^{\circ} \mathrm{C}$ and $32.2^{\circ} \mathrm{C}$. Journal of Applied Poultry Research 1995; 4:395-401.

Kidd MT, Corzo A, Hoehler D, Miler ER, Dozier WA. Broiler responsiveness (Ross $x$ 708) to diets varying in amino acid density. Poultry Science 2005; 84:1389-1396.

Macleod MG. Effects of amino acid balance and energy: protein ratio on energy and nitrogen metabolism in male broiler chickens. British Poultry Science 1997; 38:405-411.

May JD, Lott BD. Relating weight gain and feed:gain of male and female broilers to rearing temperature. Poultry Science 2001; 80: 581-584

Musharaf NA, Latshaw JD. Heat increment as affected by protein and amino acid nutrition. World's Poultry Science Journal 1999; 55:233-240

NRC. National Research Council. Nutrient requirement of poultry. $9^{\text {th }}$ ed. Washington: University Press; 1994.

Oviedo-Rondón EO, Waldroup PW. Model to estimate amino acid requirements for broiler chickens: a review. International Journal of Poultry Research 2002; 1:106-113.

Rahman MS, Pramanik AH, Basak B, Tarafdar SU, Biswas SK. Effect of feeding low protein diets on the performance of broiler during hot-humid season. International Journal of Poultry Science 2002; 1:35-39.

Rostagno HS, Albino LFT, Donzele JL, Gomes PC, Oliveira RF, Lopes DC, Ferreira AS, Barreto SLT. Tabelas brasileiras para aves e suínos: composição de alimentos e exigências nutricionais. 2. ed. Viçosa: UFV; 2005

Sakomura NK, Longo FA, Oviedo-Rondón EO, Boa-Viagem C, Ferraudo A. Modeling energy utilization and growth parameter description for broiler chickens. Poultry Science 2005; 84:13631369.

Sklan D, Noy Y. Direct determination of optimal amino acid intake for maintenance and growth in broilers. Poultry Science 2005; 84:412-418

Temim S, Chagneau AM, Guillaumin S, Michel J, Peresson R, Geraert PA, Tesseraud S. Effects of chronic heat exposure and protein intake on growth performance, nitrogen retention and muscle development in broiler chickens. Reproduction, Nutrition, Development 1999; 39:145-156.

Temim S, Chagneau AM, Guillaumin S, Michel J, Peresson R, Tesseraud $S$. Does excess dietary protein improve growth performance and carcass characteristics in heat-exposed chickens? Poultry Science 2000a; 79:312-317.

Temim S, Chagneau AM, Peresson R, Tesseraud S. Chronic heat exposure alters protein turnover of three different skeletal muscles 
in finishing broiler chickens fed 20 or $25 \%$ protein diets. Journal of Nutrition 2000b; 130:813-819.

Zarate AJ, Moran ET, Burnham DJ. Exceeding essential amino acid requirements and improving their balance as a means to minimize heat stress in broilers. Journal of Applied Poultry Research 2003a; 12:33-44.

Zarate AJ, Moran ET, Burnham DJ. Reducing crude protein and increasing limiting essential amino acid levels with summer-reared, slow- and fast-feathering broilers. Journal of Applied Poultry Research 2003b; 12:160-168.

Zuidhof MJ. Mathematical characterization of broiler carcass yield dynamics. Poultry Science 2005; 84:1108-1122. 